medRxiv preprint doi: https://doi.org/10.1101/2021.07.07.21260141; this version posted July 9, 2021. The copyright holder for this preprint (which was not certified by peer review) is the author/funder, who has granted medRxiv a license to display the preprint in perpetuity.

\title{
Myeloid-derived suppressor cells in the blood of Iranian COVID-19 patients
}

Esmaeil Mortaz ${ }^{1,2}$, Mehrnaz Movasaghi ${ }^{3}$, Ali Basiri ${ }^{4}$, Neda K. Dezfuli ${ }^{2,5}$, Neda Dalil Roofchayee ${ }^{1}$, Hamidreza Jamaati ${ }^{6}$, Johan Garssen ${ }^{7}$, Ian M. Adcock ${ }^{8}$

${ }^{1}$ Department of Immunology, Faculty of Medicine, Shahid Beheshti University of Medical Sciences, Tehran, Iran; ${ }^{2}$ Clinical Tuberculosis and Epidemiology Research Center, National Research Institute of Tuberculosis and Lung Diseases, Shahid Beheshti University of Medical Sciences, Tehran, Iran; ${ }^{3}$ Department of Pathology and Laboratory Medicine, David Geffen School of Medicine at UCLA, USA, ${ }^{4}$ Department of Chemical and Biomolecular Engineering, University of California, Los Angeles, CA, USA; ${ }^{5}$ Department of Immunology, School of Medicine, Dezful University of Medical Sciences, Dezful, Iran; ${ }^{6}$ Chronic Respiratory Diseases Research Center, National Research Institute of Tuberculosis and Lung Diseases (NRITLD), Shahid Beheshti University of Medical Sciences, Tehran, Iran; 'Division of Pharmacology, Faculty of Science, Utrecht Institute for Pharmaceutical Sciences, Utrecht University, Utrecht, Netherlands;

${ }^{8}$ National Heart and Lung Institute, Imperial College London, London, United Kingdom.

Running title: MDSCs in COVID-19

Corresponding Author: Ian M. Adcock

Email address: ian.adcock@imperial.ac.uk 
medRxiv preprint doi: https://doi.org/10.1101/2021.07.07.21260141; this version posted July 9, 2021. The copyright holder for this preprint (which was not certified by peer review) is the author/funder, who has granted medRxiv a license to display the preprint in perpetuity.

\section{Abstract}

Background: A cytokine storm and lymphopenia are reported in severe acute respiratory syndrome coronavirus 2 (SARS-CoV-2) infection associated with coronavirus disease 2019 (COVID-19). Myeloid-derived suppressive cells (MDSCs) exist in two different forms, granulocyte (G-MDSCs) and monocytic (M-MDSCs) that both suppress T-cell function. Serum IL-6 and IL-8 levels seem to correlate with the number of blood MDSCs.

Objective: To determine the frequency of MDSCs in severe COVID-19 patients from Iran and their correlations with serum IL-8 levels.

Methods: 37 severe ( 8 on ventilation, 29 without ventilation) and 13 moderate COVID19 patients together with 8 healthy subjects were enrolled at the Masih Daneshvari Hospital, Tehran-Iran between 10th April 2020-9th March 2021. Clinical and biochemical features, serum and whole blood were obtained. CD14, CD15, CD11b and HLA-DR expression on MDSCs was measured by flow cytometry.

Results: M-MDSCs ( $\mathrm{P} \leq 0.0001)$ and G-MDSCs $(P \leq 0.0001)$ frequency were higher in Iranian COVID-19 patients compared to healthy subjects. M-MDSC frequency was higher in non-ventilated compared to moderate COVID-19 subjects $(P=0.004)$. Serum IL-8 levels were higher in patients with COVID-19 than in normal healthy subjects $(P=0.03)$. IL8 level was significant difference in ventilated, non-ventilated and moderate patients $(P=0.005)$. The frequency of $G-M D S C$ s correlated negatively with INR $(r=-0.39$, $\mathrm{P}=0.02)$.

Conclusion: Serum IL-8 levels did not correlate with the number of systemic MDSCs in COVID-19 patients. The highest levels of M-MDSCs were seen in the blood of severe non-ventilated patients. MDSC frequency in blood in the current study did not predict the survival and severity of COVID-19 patients.

Keywords: MDSC, IL-8, COVID-19, peripheral blood 
medRxiv preprint doi: https://doi.org/10.1101/2021.07.07.21260141; this version posted July 9, 2021. The copyright holder for this preprint

(which was not certified by peer review) is the author/funder, who has granted medRxiv a license to display the preprint in perpetuity.

All rights reserved. No reuse allowed without permission.

\section{Introduction}

The rapid spread of severe acute respiratory syndrome coronavirus 2 (SARS-CoV-2), infection since its recognition in Wuhan China in December 2019 has resulted in a pandemic disease (1). Clinical observations suggest that SARS-CoV-2 infection can range from an asymptomatic infection through a respiratory illness with a fever and a dry cough to a severe acute respiratory distress syndrome-like disease requiring ventilation. There is a high rate of human-to-human transmission (2). In addition, the mortality rate in patients with severe coronavirus disease 2019 (COVID-19) is high (3.4\% mortality rate) (3). One of the most challenging complications of severe SARSCoV-2 infection is a respiratory pneumonia. The pathophysiology of severe diseases appears variable (4).

It is important to find markers that can predict the prognosis of COVID-19 disease. Immunological studies on two other coronavirus infections, SARS-COV1 and MERSCOV have shown that immune-based pathological mechanisms are responsible for disease severity. These pathological mechanisms include lymphopenia and unregulated immune responses $(3,5)$. Understanding the mechanism(s) and immunological patterns observed in COVID-19 is necessary for the development of effective therapeutic interventions. Myeloid derived suppressive cells (MDSCs) represent an intrinsic portion of the myeloid-cell lineage and are a heterogeneous group of relatively immature myeloid cells (6).

Several studies have described mechanisms of MDSCs mediated immune suppression (6). MDSCs are divided into granulocytic (G-MDSCs or PMN-MDSC) and monocytic (MMDSCs). In healthy individuals, immature myeloid cells (IMCs) produced in the bone marrow quickly differentiate into mature granulocytes, macrophages or dendritic cells (DCs) [7]. In cancer, sepsis, trauma, bone marrow transplantation and some autoimmune disorders, a partial block in the differentiation of IMCs into mature myeloid cells leads to an expansion MDSCs. MDSC-mediated suppression of certain T-cell function results in an excessive immune response $(6,7)$. G-MDSCs produce high levels of ROS and low levels of NO whilst the M-MDSC subset produce low levels of ROS and high levels of NO and both subsets produce arginase (8). MDSCs modulated cytokine 
medRxiv preprint doi: https://doi.org/10.1101/2021.07.07.21260141; this version posted July 9, 2021. The copyright holder for this preprint (which was not certified by peer review) is the author/funder, who has granted medRxiv a license to display the preprint in perpetuity. All rights reserved. No reuse allowed without permission.

production (9) and can promote cancer metastasis in humans and in animal models (8, 10).

However, MDSCs may play a beneficial role in acute inflammatory processes such as in dengue virus infection where they decrease the inflammatory response and the subsequent immune-mediated pathology (11). Studies have reported that G-MDSC and M-MDSC expansion occurs in the systemic circulation of mainly patients with severe COVID-19 $(3,12)$ but these changes require validation different cohort's of different ethnicity and genetic background. We hypothesised, that the frequency of MDSCs and the potential to induce immune suppression is related to the severity of COVID-19 disease in Iranian subjects. Thus, we studied the frequency of M-MDSCs and GMDSCs in the systemic circulation of in moderate and severe Iranian COVID-19 patients and determined whether this was associated with systemic inflammation as reflected by IL-8 levels.

\section{Materials and Methods}

\section{Patients}

Fifty confirmed COVID-19 patients including 8 severe patients on ventilation, 29 severe non-ventilated and 13 moderate patients were enrolled into the study upon admission to the Masih Daneshvari Hospital of Shahid Beheshti Medical University (Tehran-Iran) between 10th April 2020- 9th March, 2021. All patients were diagnosed according to World Health Organization interim guidance (13). Severe COVID-19 disease was confirmed by the presence of at least one of the following: respiratory rate $\geq 30 / \mathrm{min}$; blood oxygen saturation $\leq 93 \%$; ratio of partial pressure of oxygen in arterial blood to the inspired oxygen fraction ( $\mathrm{PaO} 2 \mathrm{FiO} 2)<300$; lung infiltrates present on $>50 \%$ of the lung field (14). Eight healthy age-matched controls were also recruited. This study was approved by the institutional ethics board of Masih Daneshvari Hospital ethical committee (IR.SBMU.NRITLD.REC.1399.122).

\section{Data collection}

The clinical records of patients were interpreted by the research team of the Department of Critical Care Medicine, Masih Daneshvari Hospital of Shahid Beheshti University. 
medRxiv preprint doi: https://doi.org/10.1101/2021.07.07.21260141; this version posted July 9, 2021. The copyright holder for this preprint (which was not certified by peer review) is the author/funder, who has granted medRxiv a license to display the preprint in perpetuity.

All rights reserved. No reuse allowed without permission.

Clinical, laboratory, and radiological properties and treatments and outcomes data were collected from electronic medical records. The information recorded included demographic data, medical history, underlying comorbidities, symptoms, signs, laboratory findings; chest computed tomographic (CT) scans, and treatment measures including antiviral therapy, corticosteroid therapy, respiratory support and kidney replacement therapy.

\section{Laboratory examination of blood samples}

Whole blood samples containing anti-coagulant EDTA $(3 \mathrm{ml})$ and with citrate $(3 \mathrm{ml})$ or no anticoagulant $(3 \mathrm{ml})$ were obtained from all participants upon admission. Tubes containing blood without anticoagulant were centrifuged, the serum collected and stored at $-80^{\circ} \mathrm{C}$ for IL-8 measurement. Serum biochemical tests including kidney and liver function tests: creatinine kinase-muscle/brain activity (CK-MB), lactate dehydrogenase $(\mathrm{LDH})$, C-reactive protein (CRP), ferritin, creatine phosphokinase (CPK), and the international normalized ratio (INR) were also performed. The erythrocyte sedimentation ratio was determined in citrate-treated whole blood samples.

\section{Cell staining and flow cytometry}

Whole blood samples $(3 \mathrm{ml})$ were collected in EDTA-treated tubes and MDSCs were analysed by flow cytometry (FACS Calibour, BD, USA). Whole blood samples were then stained with anti-CD11b APC (BD Biosciences, CA, USA), anti-HLA-DR PE (eBioscience, San Diego, CA, USA), anti-CD14 PerCP-cy5.5 (eBioscience) and antiCD15 FITC (BD Biosciences) for $30 \mathrm{~min}$ in the dark as described before $(15,16)$. Cells were then washed and suspended in FACS buffer before 20,000 events were analysed by FACS. The gating strategy was CD11b+/HLA-DR-/dim and within this population CD14+/CD15- cells and CD14-/CD15+ were identified as described previously (15, 16). Flow cytometry analysis was calculated as the frequency (percentage) of the respective subset of leukocytes and the data was subsequently analysed by FlowJO-V10 software (USA).

\section{Measurement of IL-8}


medRxiv preprint doi: https://doi.org/10.1101/2021.07.07.21260141; this version posted July 9, 2021. The copyright holder for this preprint (which was not certified by peer review) is the author/funder, who has granted medRxiv a license to display the preprint in perpetuity. All rights reserved. No reuse allowed without permission.

Serum concentrations of IL-8 were measured by linked immunosorbent assay (ELISA) (BD Biosciences, CA, USA) according to the manufacturer's protocol.

\section{Statistical analysis}

Analysis of data was performed using the SPSS program version 16.0 (SPSS, Inc. Chicago, USA) and Graph Pad Prism software (version 6; 07 Graph Pad Software, Inc.). Results were presented as the mean \pm standard deviation (SD). The measurement data between two groups were analyzed using Student's $t$-test. The nonparametric Mann-Whitney $U$ test was used for non-normally distributed variables. Difference among multiple groups was compared using one?way analysis of variance (ANOVA), $p<0.05$ was considered as statistically significant.

\section{Results}

\section{Demographic and clinical characteristics of patients with COVID-19 and healthy control subjects}

The demographic and clinical characteristics of the participants are shown in Table 1. There were no significant differences in the serum levels of ESR, CRP, LDH, Troponin, and MB activity between ICU (ventilated and non-ventilated) and non-ICU moderate COVID-19 patients. However, CPK was higher in ICU patients (ventilated and nonventilated) than non-ICU moderate patients $(P=0.01)$. (Table 1).

\section{MDSC analysis}

The frequency of M-MDSCs (HLA-DR ${ }^{-/ \operatorname{dim}} \mathrm{CD} 11 \mathrm{~b}^{+} \mathrm{CD} 14^{+} \mathrm{CD} 15^{-}$cells) and G-MDSCs (HLA-DR ${ }^{-/ 2 i m}$ CD11 $\mathrm{b}^{+} \mathrm{CD} 14^{-} \mathrm{CD} 15^{+}$cells) in the blood were evaluated as described previously (15). The gating strategy adopted and the frequency of G-MDSC and MMDSC cells in representative healthy control subjects and COVID-19 patients of differing severity are shown in Fig. 1. There was a significantly greater frequency of $\mathrm{M}$ DSCs (Fig. 2A, Table 2) and G-MDSCs (Fig. 2B, Table 2) in all COVID-19 patients as a group compared to $\mathrm{HC}(\mathrm{P} \leq 0.0001, \mathrm{P} \leq 0.0001$, respectively). 
medRxiv preprint doi: https://doi.org/10.1101/2021.07.07.21260141; this version posted July 9, 2021. The copyright holder for this preprint (which was not certified by peer review) is the author/funder, who has granted medRxiv a license to display the preprint in perpetuity. All rights reserved. No reuse allowed without permission.

Next we analysed the M-MDSC and G-MDSC cells in moderate and severe COVID-19 patients. There are significant differences in the frequency of M-MDSCs between moderate, non-ventilate and ventilated patients ( $\mathrm{P}=0.03)$ (Fig. 2C, Table 3). In addition, there was a significant increase in M-MDSC frequency in severe COVID-19 patients who were not ventilated compared to moderate patients $(P=0.004)$ (Fig. 2C, Table 3). In contrast, no significant differences were found between ventilated and non-ventilated patients in the frequency of M-MDSC (Fig. 2C). Furthermore, moderate and severe COVID-19 patients have a significantly higher frequency of M-MDSC compared with HC (Fig.2C, Table 3).

No significant differences in G-MDSC cell frequencies were found between moderate and severe COVID-19 patients although all COVID-19 groups had a higher frequency than observed for HC (Fig. 2D, Table 3).

\section{IL-8 levels}

The serum levels of IL-8 in COVID-19 patients (moderate and severe) was significantly higher than in healthy control subjects ( $P=0.03)$ (Fig. 3A, Table 2). In addition, serum IL-8 levels were significantly higher in severe COVID-19 patients on ventilation compared to those who were not ventilated $(P=0.04)$ and in moderate patients $(P=0.008)$ (Fig. 3B, Table 3). Systemic IL-8 levels were higher in non-ventilated patients than in patients with moderate COVID-19 ( $P=0.01)$ (Fig. 3B, Table 3).

\section{Correlation between M-MDSCs/G-MDSCs/IL-8 with clinical and serum parameters outcome}

The relationships between M-MDSCs and G-MDSCs frequency and IL-8 concentration with serum biochemical markers LDH, ESR, CRP, troponin, CPK, CK-MB activity and D-dimer, INR, age and arterial O2 saturation were evaluated. G-MDSC frequency correlated negatively with INR $(r=-0.39, P=0.02)$ and no other significant correlations were observed (Table 4).

\section{Discussion}


medRxiv preprint doi: https://doi.org/10.1101/2021.07.07.21260141; this version posted July 9, 2021. The copyright holder for this preprint (which was not certified by peer review) is the author/funder, who has granted medRxiv a license to display the preprint in perpetuity. All rights reserved. No reuse allowed without permission.

We demonstrated that M-MDSCs and G-MDSCs were higher in the peripheral blood of COVID-19 patients from Iran compared to healthy controls. There was a significant increase in the presence of M-MDSCs in non-ventilated compared to moderate COVID19 patients. Overall, serum IL-8 levels were significantly higher in COVID-19 patients compared to healthy controls and in severe ventilated COVID-19 patients compared to non-ventilated COVID-9 patients.

MDSCs are immature myeloid cells that suppress T cell responses (8). M-MDSC and GMDSCs expressed the IL-8 receptors CXCR1 and CXCR2 and, therefore, IL-8 may attract peripheral MDSCs to tumour sites (17). In addition, increased levels of IL-8 have been associated with more severe COVID-19 (18) although one study has reported that blood levels of IL-8 and MDSCs in ICU and non-ICU COVID-19 patients were similar (19). Bourboulis and colleagues showed that COVID-19 patients with severe respiratory failure presented with a lower percentage of HLA-DR on CD14 monocytes (20). Furthermore CD14+ HLA-DR ${ }^{\text {low }}$ cells were seen in severe COVID-19 patients and associated immune dysregulation (20). This MDSC expansion seen may account for the T cells dysregulation, particularly that of CD8 T cells, seen in COVID-19 patients who develop acute respiratory distress syndrome (21).

Agrati and co-workers showed that the percentage of G-MDSCs was increased in severe and mild COVID-19 patients (18). In contrast, COVID-19 patients during the later convalescent phase of severe disease showed a decreased frequency of MDSC cells which was linked to higher systemic levels of IL-8, IL-1 $\beta$ and TNF- $\alpha$ and reduced TGF- $\beta$ levels (18). Systemic IL-8 levels positively correlated with the duration of COVID-19 and is an important neutrophil chemoattractant with neutrophilia and the neutrophils/lymphocyte ratio (NLR) being markers of SARS-COV-2 infection (22).

We have demonstrated increased numbers of G-MDSC cells in moderate and severe COVID-19 patients and healthy control subjects but we did not find any significant difference between moderate and severe patients. In a study from Italy, PMN-MDSC frequency was higher in severe COVID-19 patients who died upon admission to hospital compared to those who survived (23). This study also reported that plasma IL-8 levels were also higher in non-survivors than in survivors upon admission, and decreased to levels comparable to those of survivors at later time points (23). However, the higher 
medRxiv preprint doi: https://doi.org/10.1101/2021.07.07.21260141; this version posted July 9, 2021. The copyright holder for this preprint (which was not certified by peer review) is the author/funder, who has granted medRxiv a license to display the preprint in perpetuity. All rights reserved. No reuse allowed without permission.

levels of serum IL-8 in ventilated COVID-19 patients in our study are consistent with other reports (23). We are unable to account for the discrepancy in the frequency of $\mathrm{G}$ MDSC cells in ventilated severe COVID-19 patients from Iran compared to Italy but suggest that this may reflect differences in treatment and/or ethnicity between subjects in Iran and Italy or possibly the number of subjects studied. Overall, our data does not support the hypothesis that MDSCs are a predictor of COVID-19 outcomes.

In the current study we have also seen a difference in IL-8 levels between ventilated and non-ventilated severe COVID-19 patients and that both groups had higher IL-8 levels than in moderate disease and in healthy controls. Furthermore, there were no differences in peripheral blood G-MDSC frequency between COVID-19 patients with different severities although they were all groups of patients were higher than healthy control subjects. In contrast, the frequency of M-MDSC in the blood of non-ventilated severe COVID-19 patients was higher than patients with moderate disease.

We did not find any link between systemic IL-8 levels and the proportion of MDSC cells in blood. This suggests that either other factors are responsible for the production of MDSCs in these patients or that the enhanced blood levels of IL-8 reflect much higher levels in the lung and other COVID-19-infected tissues and this results in margination to these tissues. This may be even more evident in patients with very severe disease who are on ventilation where margination of M-MDSCs from the blood to the lung or kidney results in suppression of the local immune response. Future studies are required using matched peripheral blood and lung samples, for example, to determine whether this is indeed the case. A recent study indicated that M-MDSC frequency is enhanced in blood but not in the upper airways of COVID-19 patients (12).

In HIV-1 patients, the expansion of MDSCs promotes the differentiation of regulatory $\mathrm{T}$ cells and thereby control T cell differentiation and function (24). Thus, in HIV-1 patients MDSCs play a role in countering viral persistence and may suggest a new immunotherapeutic strategy against human viral diseases (24). Moreover, increased levels of M-MDSCs strongly correlates with a worse outcome in septic shock (25). MDSCs play a dual role in patients with sepsis (26) being beneficial by reducing inflammation during early stage disease stage whilst in the latter stages of disease they are able to induce long term immunosuppression $(18,26)$. 
medRxiv preprint doi: https://doi.org/10.1101/2021.07.07.21260141; this version posted July 9, 2021. The copyright holder for this preprint (which was not certified by peer review) is the author/funder, who has granted medRxiv a license to display the preprint in perpetuity.

All rights reserved. No reuse allowed without permission.

In summary, our data in Iranian patients are in line with other studies showing increased IL-8 in the peripheral blood of COVID-19 patients and that higher expression was associated with worse clinical outcomes. This may lead to the expansion and recruitment of MDSC cells and that targeting this cytokine-MDSC network may provide a new approach to improve clinical outcomes of COVID-19 patients. 
medRxiv preprint doi: https://doi.org/10.1101/2021.07.07.21260141; this version posted July 9, 2021. The copyright holder for this preprint

\section{Declarations and footnotes:}

\section{ETHICS STATEMENT}

The studies involving human participants were reviewed and approved by Masih Daneshvari Hospital ethical Board. The patients/participants provided their written informed consent to participate in this study.

\section{AUTHOR CONTRIBUTIONS}

EM, NKD and NDR did experiments. EM wrote the draft of paper. MM, AB, HG, JG revised the paper. IA approved the final version as corresponding author. All authors contributed to the article and approved the submitted version.

\section{FUNDING}

This study was supported by the authors own funds.

\section{CONFLICT OF INTEREST}

The authors confirm that there are no conflicts of interests.

\section{ACKNOWLEDGMENTS}

We acknowledge all study participants whom are alive and remember those patients in this study who died of COVID-19. 
medRxiv preprint doi: https://doi.org/10.1101/2021.07.07.21260141; this version posted July 9, 2021. The copyright holder for this preprint (which was not certified by peer review) is the author/funder, who has granted medRxiv a license to display the preprint in perpetuity.

Figure legends:

Figure 1: Gating strategy for M-MDSC and G-MDSC cells.

Representative dot plots of flow cytometry data M-MDSCs (HLA-DR

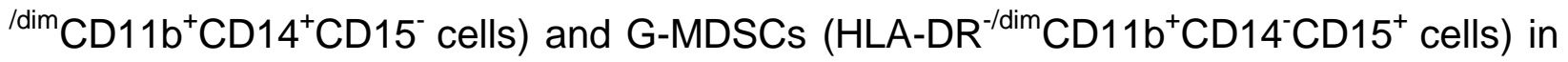

the blood of a HC (A) and moderate (B) non-ventilated ICU (C) and ventilated ICU (D) patients frequency of cells are indicated in the text boxes in the top left (M-MDSC) and bottom right (G-MDSC) panels.

Figure 2: Frequency of M-MDSCs and G-MDSCs in COVID-19 patients and healthy controls subjects.

Dot plot of the frequency of M-MDSCs (A) and G-MDSCs (B) between COVID-19 patients compared to $\mathrm{HC}$.

C) Frequency of M-MDSCs individually was calculated. Individual values for each subject with the mean (SD) in severe COVID-19 patients admitted to the intensive care unit (ICU) who were either ventilated or non-ventilated or who had moderate disease and were not admitted to the ICU presented as dot plot.

$(\longmapsto$ : shows significant between two groups by using t-test or Mann-Whitney $U$ test, $\square$ : shows statistic differences among ventilated, non-ventilated and moderate patients by using one?way analysis of variance)

D) Frequency of G-MDSCs individually was calculated and presented as dot plot. $(\longmapsto$ : shows significant between two marked groups groups.

$\square$; shows significant between two groups by using t-test or Mann-Whitney $U$ test

$\sqcap$ : shows statistic differences among ventilated, non-ventilated and moderate patients by using one?way analysis of variance 
medRxiv preprint doi: https://doi.org/10.1101/2021.07.07.21260141; this version posted July 9, 2021. The copyright holder for this preprint (which was not certified by peer review) is the author/funder, who has granted medRxiv a license to display the preprint in perpetuity.

\section{Figure 3: IL-8 level in COVID-19 patients}

Serum IL-8 concentration in COVID-19 patients versus HC (A). Serum IL-8 levels in severe COVID-19 patients admitted to the intensive care unit (ICU) who were either ventilated or non-ventilated or had moderate disease (B). Results are presented as dot plots of individual values for each subject with the mean (SD)

$(\vdash$ : shows significant between two groups by using t-test or Mann-Whitney $U$ test, $\square$ : shows statistic differences among ventilated, non-ventilated and moderate patients by using one? way analysis of variance). 
medRxiv preprint doi: https://doi.org/10.1101/2021.07.07.21260141; this version posted July 9, 2021. The copyright holder for this preprint (which was not certified by peer review) is the author/funder, who has granted medRxiv a license to display the preprint in perpetuity.

All rights reserved. No reuse allowed without permission.

Table 1: The demographic data and biochemical characters of participants.

\begin{tabular}{|c|c|c|c|c|c|c|}
\hline & \multicolumn{2}{|c|}{ S (ICU) } & \multirow{2}{*}{$\begin{array}{c}M(\text { Non-ICU) } \\
N=13\end{array}$} & \multirow{2}{*}{$\begin{array}{l}\mathrm{HC} \\
\mathrm{N}=8\end{array}$} & \multicolumn{2}{|c|}{$P$ value } \\
\hline & $\begin{array}{c}V \\
N=8\end{array}$ & $\begin{array}{c}N V \\
N=29\end{array}$ & & & $\begin{array}{c}\text { ICU } \\
\text { Vs. N-ICU }\end{array}$ & $\begin{array}{c}\text { V vs. NV } \\
\text { vs. } M\end{array}$ \\
\hline Age, years & $62.1 \pm 9.5$ & $58.3 \pm 13.2$ & $50.0 \pm 16.8$ & $40.1 \pm 10$ & 0.04 & 0.10 \\
\hline Female, $\mathbf{N}(\%)$ & $5(62.5)$ & $13(44.8)$ & $7(53.8)$ & $1(12.5)$ & - & - \\
\hline Male, N (\%) & $3(37.5)$ & $16(55.2)$ & $6(46.2)$ & $7(87.5)$ & - & - \\
\hline $\operatorname{ESR}(\mathrm{mm} / \mathrm{hr})$ & $\begin{array}{c}52.0 \pm 31.9 \\
N=7\end{array}$ & $\begin{array}{c}35.3 \pm 29.1 \\
N=21\end{array}$ & $\begin{array}{c}44.0 \pm 37.3 \\
\mathrm{~N}=12\end{array}$ & - & 0.69 & 0.46 \\
\hline CRP (mg/l) & $\begin{array}{c}26.7 \pm 12.4 \\
N=4\end{array}$ & $\begin{array}{c}40.6 \pm 25.6 \\
N=22\end{array}$ & $\begin{array}{c}40.0 \pm 19.11 \\
\mathrm{~N}=4\end{array}$ & - & 0.91 & 0.56 \\
\hline LDH (U/L) & $\begin{array}{c}677.1 \pm 459.1 \\
N=7\end{array}$ & $\begin{array}{c}577.1 \pm 253.6 \\
N=26\end{array}$ & $\begin{array}{c}492.9 \pm 124.4 \\
N=11\end{array}$ & - & 0.27 & 0.37 \\
\hline Troponin (pg/ml) & $\begin{array}{c}0.02 \pm 0.0 \\
N=4\end{array}$ & $\begin{array}{c}0.11 \pm 0.43 \\
\mathrm{~N}=22\end{array}$ & $\begin{array}{c}0.02 \pm 0.0 \\
N=3\end{array}$ & - & 0.74 & 0.87 \\
\hline CPK (U/L) & $\begin{array}{c}246.1 \pm 301.6 \\
N=7\end{array}$ & $\begin{array}{c}215.4 \pm 295.9 \\
N=26\end{array}$ & $\begin{array}{c}85.1 \pm 63.23 \\
N=10\end{array}$ & - & 0.01 & 0.35 \\
\hline D-Dimer (ng/ml) & $\begin{array}{c}556.5 \pm 456.0 \\
N=2\end{array}$ & $\begin{array}{c}1167.8 \pm 1351.1 \\
N=22\end{array}$ & $\begin{array}{c}3945.0 \pm 4320.4 \\
N=2\end{array}$ & - & 0.52 & 0.06 \\
\hline CK-MB Activity (U/L) & $\begin{array}{c}45.6 \pm 36.6 \\
N=3\end{array}$ & $\begin{array}{c}44.7 \pm 48.1 \\
N=19\end{array}$ & $\begin{array}{c}40.0 \pm 16.9 \\
N=2\end{array}$ & - & 0.88 & 0.98 \\
\hline O2 Saturation \% & $\begin{array}{c}87.3 \pm 7.8 \\
N=3\end{array}$ & $\begin{array}{c}65.5 \pm 23.2 \\
N=22\end{array}$ & $\begin{array}{c}75.0 \pm 24.4 \\
N=4\end{array}$ & - & 0.58 & 0.27 \\
\hline INR & $\begin{array}{c}1.1 \pm 0.05 \\
N=4\end{array}$ & $\begin{array}{c}1.1 \pm 0.12 \\
N=23\end{array}$ & $\begin{array}{c}1.1 \pm 0.13 \\
N=4\end{array}$ & - & 0.43 & 0.60 \\
\hline
\end{tabular}

${ }^{*}$ Values were presented as Mean \pm SD. $\mathrm{p}<0.05$ was considered significant

$\mathrm{N}$ numbers are for whole group unless otherwise indicated.

Abbreviations: CK-MB: creatinine kinase-muscle/brain; CPK: creatine phosphokinase CRP: Creactive protein; ESR: erythrocyte sedimentation rate; INR: international normalized ratio; LDH: lactate dehydrogenase;

HC: Healthy control; M: Moderate; S: Severe; ICU: Intensive care unit; NV: Non-ventilated; V: Ventilated 
medRxiv preprint doi: https://doi.org/10.1101/2021.07.07.21260141; this version posted July 9, 2021. The copyright holder for this preprint (which was not certified by peer review) is the author/funder, who has granted medRxiv a license to display the preprint in perpetuity.

All rights reserved. No reuse allowed without permission.

Table 2: The frequency of MDSCs and serum levels of IL-8 in COVID-19 patients and healthy controls

\begin{tabular}{|l|c|c|c|}
\hline & COVID-19 Patients & HC & P value \\
\hline M-MDSC (\%) & $\begin{array}{c}12.7 \pm 13.3 \\
\mathrm{~N}=48\end{array}$ & $\begin{array}{c}0.19 \pm 0.20 \\
\mathrm{~N}=8\end{array}$ & $\leq .0001$ \\
\hline G-MDSC (\%) & $\begin{array}{c}15.8 \pm 12.6 \\
\mathrm{~N}=50\end{array}$ & $\begin{array}{c}0.35 \pm 0.40 \\
\mathrm{~N}=8\end{array}$ & $\leq 0.0001$ \\
\hline IL-8 & $\begin{array}{c}6.4 \pm 7.8 \\
\mathrm{~N}=32\end{array}$ & $\begin{array}{c}0.10 \pm 0.0 \\
\mathrm{~N}=8\end{array}$ & 0.03 \\
\hline
\end{tabular}

Values were presented as Mean \pm SD. $p<0.05$ was considered significant

$\mathrm{HC}$; Healthy control 
Table 3: The percentage of MDSCs and levels of serum IL-8 in severe COVID-19 patients according to ICU status

\begin{tabular}{|c|c|c|c|c|c|c|c|c|c|c|c|}
\hline & \multirow[t]{2}{*}{$\mathrm{HC}$} & \multirow[t]{2}{*}{$\mathbf{M}$} & \multicolumn{2}{|c|}{$\mathbf{S}$} & \multirow[b]{2}{*}{$\begin{array}{c}\text { M vs. } \\
\text { HC }\end{array}$} & \multicolumn{6}{|c|}{ P value } \\
\hline & & & NV & V & & $\begin{array}{c}\text { NV vs. } \\
\text { HC }\end{array}$ & $\begin{array}{c}\text { V vs. } \\
\text { HC }\end{array}$ & $\begin{array}{l}\text { V vs. NV } \\
\text { vs. M }\end{array}$ & $\begin{array}{c}\text { NV vs. } \\
\text { M }\end{array}$ & V vs. M & $\begin{array}{c}\text { NV vs. } \\
\text { V }\end{array}$ \\
\hline M-MDSC (\%) & $0.19 \pm 0.20$ & $\begin{array}{c}5.4 \pm 4.8 \\
N=13\end{array}$ & $\begin{array}{c}16.8 \pm 15.8 \\
N=27\end{array}$ & $\begin{array}{c}10.3 \pm 6.4 \\
N=8\end{array}$ & 0.0006 & $\leq 0.0001$ & 0.0002 & 0.03 & 0.004 & 0.06 & 0.43 \\
\hline G-MDSC (\%) & $0.35 \pm 0.40$ & $\begin{array}{c}11.8 \pm 11.6 \\
\mathrm{~N}=13\end{array}$ & $\begin{array}{c}17.6 \pm 13.6 \\
N=29\end{array}$ & $\begin{array}{c}15.6 \pm 10.0 \\
N=8\end{array}$ & $\leq 0.0001$ & $\leq 0.0001$ & 0.0002 & 0.40 & 0.19 & 0.46 & 0.70 \\
\hline IL-8 & $0.10 \pm 0.00$ & $\begin{array}{c}2.8 \pm 3.0 \\
N=10\end{array}$ & $\begin{array}{c}5.7 \pm 2.7 \\
N=17\end{array}$ & $\begin{array}{c}15.7 \pm 16.7 \\
N=5\end{array}$ & 0.02 & $\leq 0.0001$ & 0.02 & 0.005 & 0.01 & 0.008 & 0.04 \\
\hline
\end{tabular}

Values were presented as Mean \pm SD. $p<0.05$ was considered significant.

\section{Abbreviations:}

HC: Healthy Controls

M: Moderate

S: Severe

V: Ventilated

NV: Non Ventilated 
Table 4: Correlation analysis between M-MDSC, G-MDSC, IL-8 and other factors in COVID-19 patients

\begin{tabular}{|c|c|c|c|c|c|c|c|c|c|c|c|c|c|c|c|c|c|c|c|c|c|c|}
\hline & \multicolumn{2}{|c|}{ ESR } & \multicolumn{2}{|c|}{ CRP } & \multicolumn{2}{|c|}{ LDH } & \multicolumn{2}{|c|}{ CPK } & \multicolumn{2}{|c|}{ Troponin } & \multicolumn{2}{|c|}{ CK-MB } & \multicolumn{2}{|c|}{ O2 sat\% } & \multicolumn{2}{|c|}{ D-Dimer } & \multicolumn{2}{|c|}{ INR } & \multicolumn{2}{|c|}{ Age } & \multicolumn{2}{|c|}{ IL-8 } \\
\hline & $r$ & $p$ & $r$ & $p$ & $r$ & $p$ & $r$ & $p$ & $r$ & $p$ & $r$ & $p$ & $r$ & $p$ & $r$ & $p$ & $r$ & $p$ & $r$ & $\mathbf{p}$ & $r$ & $p$ \\
\hline M-MDSC & 0.01 & 0.95 & 0.004 & 0.98 & -0.04 & 0.75 & -0.10 & 0.52 & -0.10 & 0.59 & -0.12 & 0.58 & -0.30 & 0.12 & -0.26 & 0.21 & -0.12 & 0.53 & 0.12 & 0.40 & 0.03 & 0.85 \\
\hline G-MDSC & 0.05 & 0.74 & 0.12 & 0.51 & 0.14 & 0.33 & -0.09 & 0.55 & -0.20 & 0.29 & -0.31 & 0.12 & -0.10 & 0.58 & -0.27 & 0.17 & -0.39 & 0.02 & -0.12 & 0.39 & -0.03 & 0.84 \\
\hline IL-8 & 0.008 & 0.96 & -0.23 & 0.27 & 0.14 & 0.45 & 0.10 & 0.57 & 0.11 & 0.60 & 0.22 & 0.28 & 0.17 & 0.41 & -0.26 & 0.27 & -0.15 & 0.46 & 0.25 & 0.16 & - & - \\
\hline
\end{tabular}

$r$ : Pearson correlation coefficient, p: $p$-value

Abbreviations: CK-MB: creatinine kinase-muscle/brain; CPK: creatine phosphokinase CRP: C-reactive protein; ESR: erythrocyte sedimentation rate; INR: international normalized ratio; LDH: lactate dehydrogenase 
medRxiv preprint doi: https://doi.org/10.1101/2021.07.07.21260141; this version posted July 9,2021 . The copyright holder for this preprint (which was not certified by peer review) is the author/funder, who has granted medRxiv a license to display the preprint in perpetuity.

All rights reserved. No reuse allowed without permission.

\section{References:}

1. Le Bert N, Tan AT, Kunasegaran K, Tham CY, Hafezi M, Chia A, et al. SARS-CoV-2specific T cell immunity in cases of COVID-19 and SARS, and uninfected controls. Nature. 2020;584(7821):457-62.

2. Mortaz E, Tabarsi P, Varahram M, Folkerts G, Adcock IM. The Immune Response and Immunopathology of COVID-19. Front Immunol. 2020;11:2037.

3. Agrati C, Sacchi A, Bordoni V, Cimini E, Notari S, Grassi G, et al. Expansion of myeloidderived suppressor cells in patients with severe coronavirus disease (COVID-19). Cell Death \& Differentiation. 2020:1-12.

4. Sette A, Crotty S. Pre-existing immunity to SARS-CoV-2: the knowns and unknowns. Nature Reviews Immunology. 2020;20(8):457-8.

5. Nikolich-Zugich J, Knox KS, Rios CT, Natt B, Bhattacharya D, Fain MJ. SARS-CoV-2 and COVID-19 in older adults: what we may expect regarding pathogenesis, immune responses, and outcomes. Geroscience. 2020:1-10.

6. Gabrilovich DI, Nagaraj S. Myeloid-derived suppressor cells as regulators of the immune system. Nature reviews immunology. 2009;9(3):162-74.

7. Ostrand-Rosenberg S, Sinha P. Myeloid-derived suppressor cells: linking inflammation and cancer. The Journal of Immunology. 2009;182(8):4499-506.

8. Gabrilovich DI, Nagaraj S. Myeloid-derived suppressor cells as regulators of the immune system. Nature reviews Immunology. 2009;9(3):162-74.

9. Sinha P CV, Bunt SK, Albelda SM, Ostrand-Rosenberg S. . Crosstalk between myeloidderived suppressor cells and macrophages subverts tumor immunity toward a type 2 response. Journal of immunology. 2007;179:977-83.

10. Murdoch C MM, Coffelt SB, Lewis CE. The role of myeloid cells in the promotion of tumour angiogenesis. Nat Rev Cancer. 2008;8:618-31.

11. Guo PL, Li LH, Li WL, Zhao JC, Hu FY, Zhang FC, et al. The clinical significance of myeloid-derived suppressor cells in dengue fever patients. BMC Infect Dis. 2019;19(1):926.

12. Falck-Jones S, Vangeti S, Yu M, Falck-Jones R, Cagigi A, Badolati I, et al. Functional monocytic myeloid-derived suppressor cells increase in blood but not airways and predict COVID-19 severity. J Clin Invest. 2021:DOI:10.1172/JCI144734.

13. World Health $\mathrm{O}$. Clinical management of severe acute respiratory infection (SARI) when COVID-19 disease is suspected. Interim guidance. Pediatria i Medycyna Rodzinna. 2020;16(1):9-26.

14. Lee DW, Gardner R, Porter DL, Louis CU, Ahmed N, Jensen M, et al. Current concepts in the diagnosis and management of cytokine release syndrome. Blood. 2014;124(2):188-95.

15. al. Ye. Circulating and Tumor Myeloid-derived Suppressor Cells in Resectable NonSmall Cell Lung Cancer. Am J Respir Crit Care Med. 2018;198(6):777-87.

16. Apodaca MC, Wright AE, Riggins AM, Harris WP, Yeung RS, Yu L, et al. Characterization of a whole blood assay for quantifying myeloid-derived suppressor cells. Journal for immunotherapy of cancer. 2019;7(1):230.

17. Tobin RP, Jordan KR, Kapoor P, Spongberg E, Davis D, Vorwald VM, et al. IL-6 and IL-8 Are Linked With Myeloid-Derived Suppressor Cell Accumulation and Correlate With Poor Clinical Outcomes in Melanoma Patients. Frontiers in oncology. 2019;9:1223.

18. Agrati C, Sacchi A, Bordoni V, Cimini E, Notari S, Grassi G, et al. Expansion of myeloidderived suppressor cells in patients with severe coronavirus disease (COVID-19). Cell death and differentiation. 2020;27(11):3196-207.

19. Bordoni V, Sacchi A, Cimini E, Notari S, Grassi G, Tartaglia E, et al. An Inflammatory Profile Correlates With Decreased Frequency of Cytotoxic Cells in Coronavirus Disease 2019. Clinical infectious diseases : an official publication of the Infectious Diseases Society of America. 2020;71(16):2272-5. 
medRxiv preprint doi: https://doi.org/10.1101/2021.07.07.21260141; this version posted July 9, 2021. The copyright holder for this preprint (which was not certified by peer review) is the author/funder, who has granted medRxiv a license to display the preprint in perpetuity. All rights reserved. No reuse allowed without permission.

20. Giamarellos-Bourboulis EJ NM, Rovina N, et al. Complex Immune Dysregulation in COVID-19 Patients with Severe Respiratory Failure. Cell Host Microbe 2020;270:992-1000.

21. Reizine F, Lesouhaitier M, Gregoire M, Pinceaux K, Gacouin A, Maamar A, et al. SARSCoV-2-Induced ARDS Associates with MDSC Expansion, Lymphocyte Dysfunction, and Arginine Shortage. J Clin Immunol. 2021;41(3):515-25.

22. Ma A, Zhang L, Ye X, Chen J, Yu J, Zhuang L, et al. High Levels of Circulating IL-8 and Soluble IL-2R Are Associated With Prolonged IIIness in Patients With Severe COVID-19. Front Immunol. 2021;12:626235.

23. Sacchi A, Grassi G, Bordoni V, Lorenzini P, Cimini E, Casetti R, et al. Early expansion of myeloid-derived suppressor cells inhibits SARS-CoV-2 specific T-cell response and may predict fatal COVID-19 outcome. Cell death \& disease. 2020;11(10):921.

24. Wang L, Zhao J, Ren JP, Wu XY, Morrison ZD, Elgazzar MA, et al. Expansion of myeloid-derived suppressor cells promotes differentiation of regulatory $\mathrm{T}$ cells in HIV-1+ individuals. Aids. 2016;30(10):1521-31.

25. Waeckel L VF, Gossez M, Monard C, Rimmelé T, Monneret G. . Delayed persistence of elevated monocytic MDSC associates with deleterious outcomes in septic shock: a retrospective cohort study. . Crit Care 2020;24:132.

26. Schrijver IT, Theroude C, Roger T. Myeloid-Derived Suppressor Cells in Sepsis. Front Immunol. 2019;10:327. 

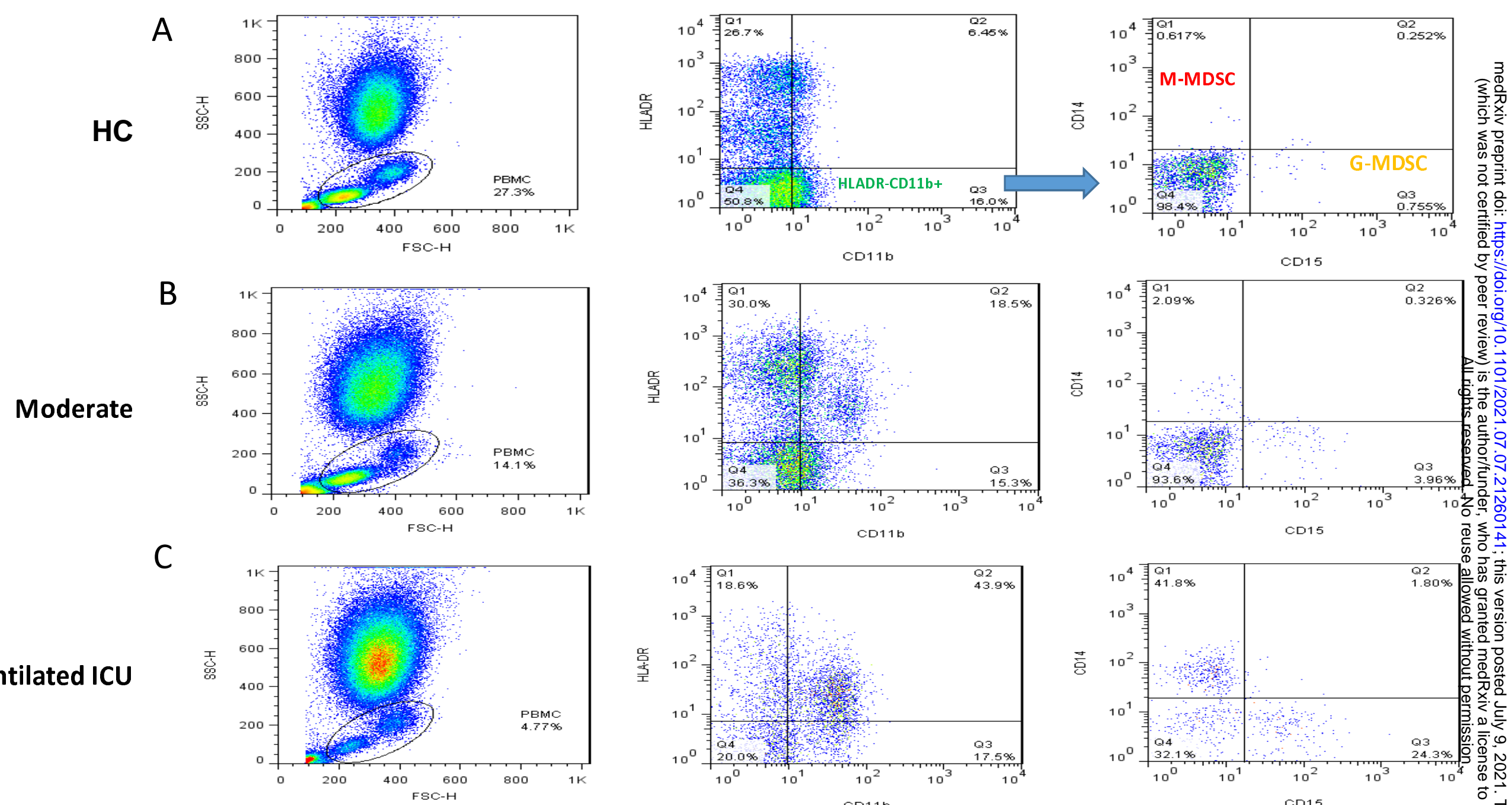

\section{Non-ventilated ICU}

Ventilated ICU
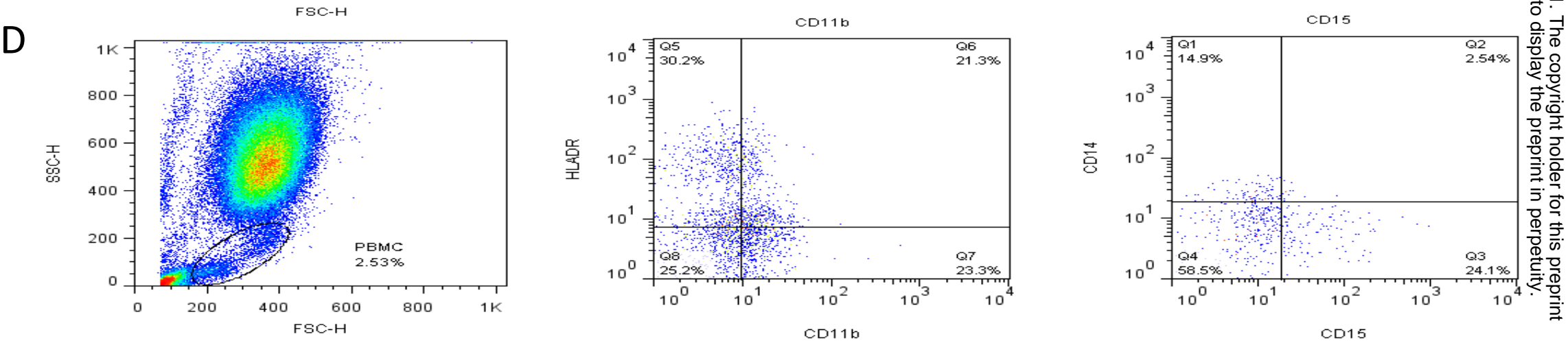
A

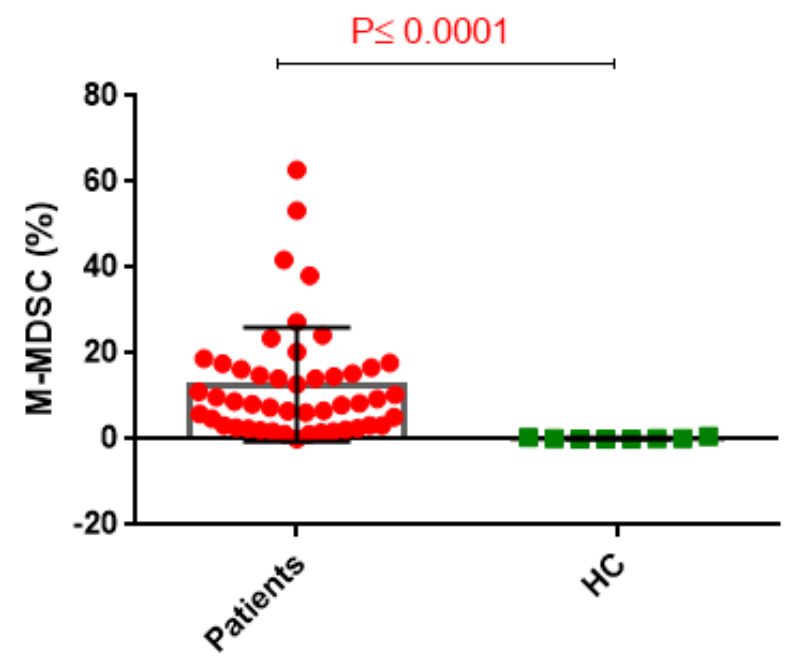

C

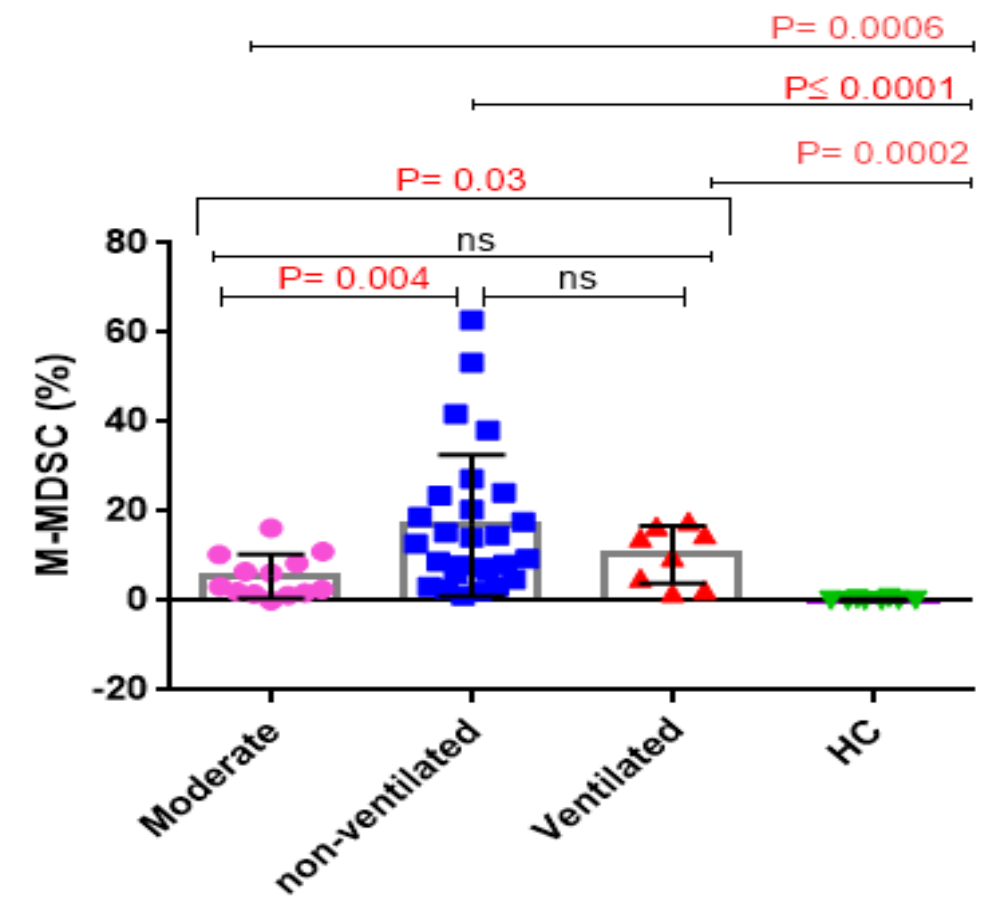

B

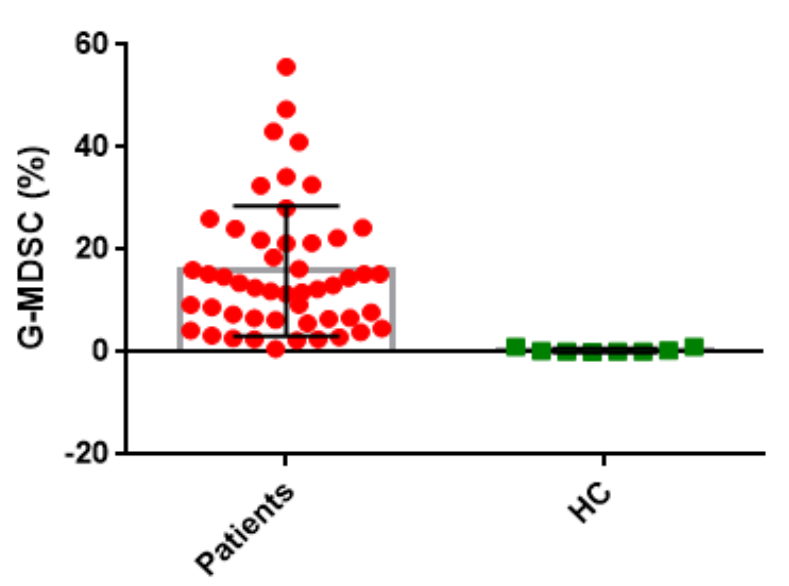

D

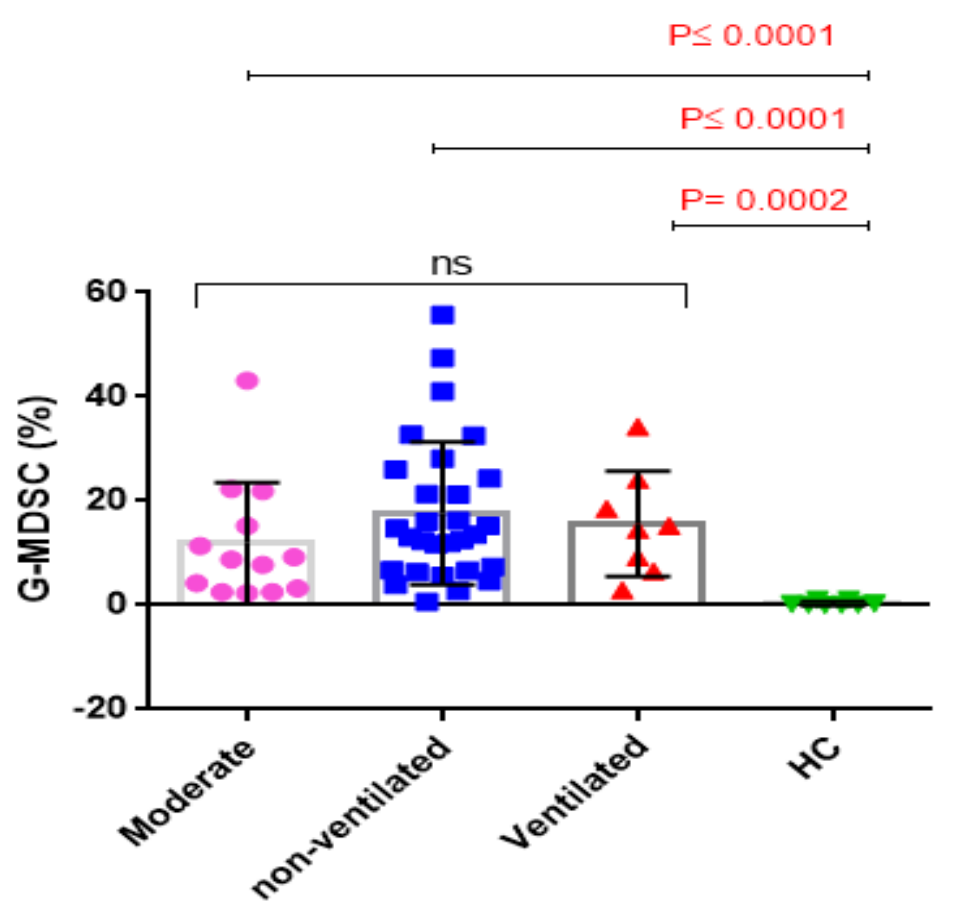



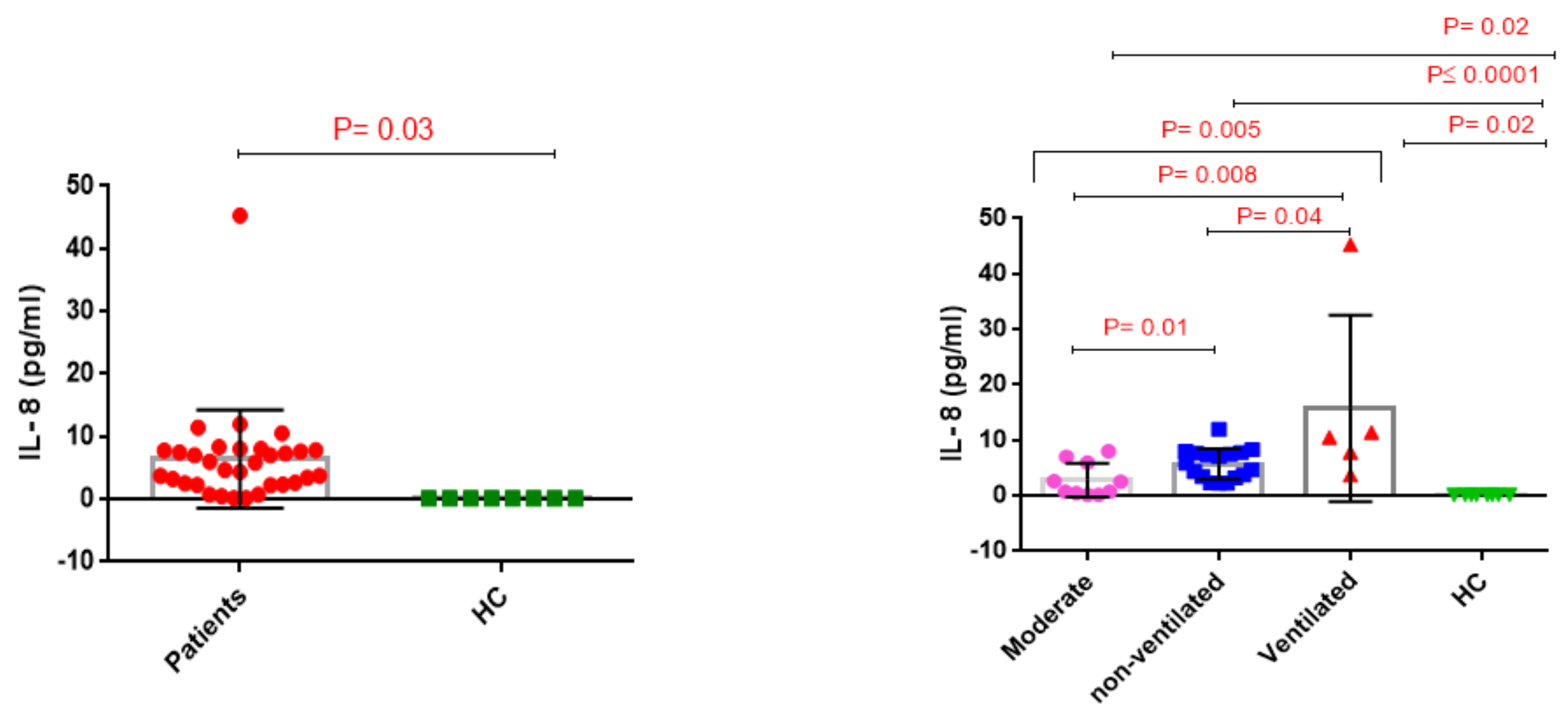